\title{
The Factors That Influence the Creativity of Employee in Three Star Hotel
}

\author{
Evi Silvana Muchsinati*, Regina Michelle Hawidi \\ Management Study Program \\ Universitas Internasional Batam \\ Batam, Indonesia \\ *evi@uib.ac.id
}

\begin{abstract}
Creativity can be meant as the new idea, that is useful for product, service, process or procedure developed by the employee in a social system, which they will collaborate with others. Creativities of the hotel employee are very necessary to create a new idea and make a strategy to develop the hotel business. The level of creativity is also the main key to defend the existence of a hotel. The research is aim to find out the factor that influences the creativity of the hotel employee in a three-star hotel in Batam. How the hotel gives the best service to the customer with the human resources and employee that have good leadership and soul to share the knowledge of each other. A creative employee that always want to innovate. This research uses 123 employees from 11 three-star hotel in Batam. This research doesn't use the whole employee in the hotel because the researcher only wants to investigate the department of the hotel that need to use the high creativity. The data will be tested by the SmartPLS application. The result of the research shows that intention to share the knowledge that influences significantly with the employee creativity through the leader-member exchange as mediation at a three-star hotel. The value of this study to explore mediation model leader-member exchange to employee creativity at three-star hotel Batam.
\end{abstract}

Keywords-intention to share knowledge, leader member exchange, employee creativity, mediation

\section{INTRODUCTION}

Previous study that importance of creativity in the tourism and hospitality had conducted researcher [1-4]. Nowadays the hotel in Indonesia not only compete with the building location but also the creativity of the employee of giving service. In 2017, the tourist come to Batam is 1.507.213 and 2018, the tourists come to Batam are 1.887.244 based on the data of BPS Batam city. The increase of the visit of the tourist Batam City on 2017 to 2018 is 380.031 [5]. The hotel company nowadays compete each other to fulfill the market want that need a quality of better service. That why, the hotel company nowadays more strengthen the strategy to compete in order to have good quality in hotel sector. The quality of hotel service is the main factor to hotel management.

Knowledge is the important natural source to conserve the worthy heritage, learning new technique, solving problem, create main completion and begin a new situation. The various of knowledge is used as the basic way of being creative in an organization, but it is very important to the employee to take the initiative for sharing their knowledge to the others. The leader of the team or organization has an influence to the climate of creativity in various important way that is the main in leadership for creativity because to keep the employee creative, motivated and involved [6]. The good relation between the employer and employee, make the employee dare to ask question and ask for a help. The lack of innovation of the hotel influence the visitor to stay in the hotel, example, the uninterested promotion, the media promotion is not up to date, the unsatisfied hotel service. So that a suggestion and advise are needed to improve the quality of the hotel service. One of the factors, that influence the occupation of the hotel is the review and the comment of the visitor. The review of the hote can be given or seen in media online, example Tripadvisor, Traveloka, Pegipegi, and Ticket.com. If the majority of the reviews are positive, it will interest the visitor to come to the hotel, but if the review is negative, the visitor will think twice to come to the hotel that give influence to the hotel and the worst is the hotel get bankrupt. Some examples to improve the quality of the employee creativity is looking for the potency of the employee and develop it by given informal training, learning from other, on job training, and how the leader build good relation. The IT employee make interest media promotion by website, promotion on special events or special day, giving discount with credit card or debit, giving special priced, take and pick the guest from the airport to hotel and from hotel to airport. Or making interesting web.

\section{LITERATURE REVIEW}

\section{A. Intention to Share Knowledge to Employee Creativity}

Knowledge is important natural resource to conserve the worthy heritage. Learning new technique, solving problem, creating the main competent and begin a new situation [7]. Various knowledge has function as the basic to be creative in an organization, but it is needed for employee to take initiative to share their knowledge to the others. That's why the research explore how the employee use that sharing knowledge as the 
strategy to influence the organization. In tourism industry, sharing knowledge is important, because they need to exchange the information and knowledge quickly to create new creative idea, and that will take turn to satisfy the costumer [8]. Empiric study also show that share knowledge can increase the creativity work of student, especially in tourism management context and hotel. Based on the investigation that intention to share knowledge has connection with employee creativity [9]. By sharing knowledge, the employee can coordinate the relevant information with others in team or organization [10,11]. Sharing knowledge among the individual in organization is important process $[12,13]$. The previous study shows the main function of sharing knowledge is to maintain mechanism among the personnel of every unit to continue the creativity and innovation. Most of the research of creativity focus on the individual level $[13,14]$. Most of the research agree that individual creativity is the beginning spot and as the requirement for innovating in organization.

H1: There is an influence to intention to share knowledge to employee creativity

\section{B. Mediating Role of the $L M X$}

Leader member exchange have positive influence to employee creativity [15]. We watch that employee intention to share knowledge influence leader member exchange positively and Leader Member Exchange. Leader member exchange and team identification have positive influence on employee creativity [15]. Another reseach also indicated LMX positive influence individual creativity $[16,17]$.

H2: Leader-member exchange mediate relation between intention to share knowledge and employee creativity.

The factors that influence can be seen in figure 1.

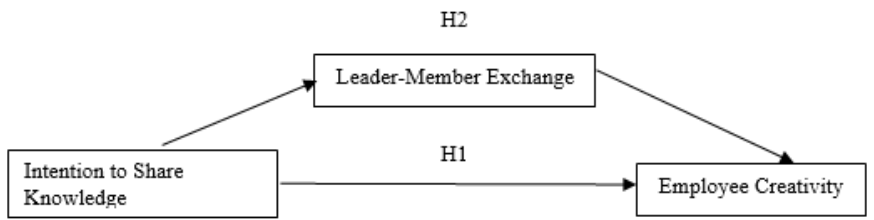

Fig. 1. The factors that influence the creativity of employee in three star hotel $[9,14]$.

\section{METHODS}

Population that is used in this research is the whole employee in three-star hotel in Batam. The reason chose hotel as the object of research is as the opinion of property, the hotel development in Batam is rapid. Batam is an area that attract investor and international tourist [18]. The researcher used the technique to take sample by non-probability sample which the technique is purposive sampling. The sample used by the research is the employee of three-star hotel in Lubuk Baja and Batu Ampar district, because those two district have the most amount of three-star hotel in Batam, can be seen on table 1.
TABLE I. THE AMOUNT OF THREE-STAR HOTEL BASED ON DistRICT IN BATAM

\begin{tabular}{|l|l|l|}
\hline Number & \multicolumn{1}{|c|}{ District } & Hotel \\
\hline 1 & Batam Kota & 5 \\
\hline 2 & Batu Aji & 1 \\
\hline 3 & Batu Ampar & 7 \\
\hline 4 & Bengkong & 4 \\
\hline 5 & Lubuk Baja & 12 \\
\hline 6 & Sekupang & 2 \\
\hline \multicolumn{2}{|c|}{ Source : http//batamkota.Bps, 2019. }
\end{tabular}

As seen on the table 2 and 3 , is the number of employee from department sales, HRD, Receptionist, and chef.

TABLE II. The Amount OF EMPLOYEE Hotel IN LUBUK BAJA DISTRICT

\begin{tabular}{|l|l|l|}
\hline Number & \multicolumn{1}{|c|}{$\begin{array}{c}\text { Hotel in Lubuk Baja } \\
\text { District }\end{array}$} & $\begin{array}{c}\text { The amount of } \\
\text { employee }\end{array}$ \\
\hline 1 & Batam City Hotel & 14 \\
\hline 2 & Da Vienna Hotel & 20 \\
\hline 3 & Gideon Hotel & 14 \\
\hline 4 & Nagoya Plasa Hotel & 7 \\
\hline 5 & Swiss Inn Hotel & 9 \\
\hline 6 & Utama Hotel & 7 \\
\hline & Total & 71 \\
\hline
\end{tabular}

TABLE III. The AMOUNT OF EMPlOYEe Hotel IN BATU AMPAR DISTRICT

\begin{tabular}{|l|l|l|}
\hline Number & \multicolumn{1}{|c|}{$\begin{array}{c}\text { Hotel in Batu Ampar } \\
\text { District }\end{array}$} & \multicolumn{1}{c|}{$\begin{array}{c}\text { The amount of } \\
\text { employee }\end{array}$} \\
\hline 1 & Barelang Hotel & 6 \\
\hline 2 & $\begin{array}{l}\text { Batam Habour Boutique } \\
\text { Hotel \& Spa }\end{array}$ & 15 \\
\hline 3 & Harmoni Hotel & 12 \\
\hline 4 & The Hills Hotel & 8 \\
\hline 5 & King Hotel & 11 \\
\hline & Total & 52 \\
\hline
\end{tabular}

The analysis unit data in this research is individual. Because respondent in this research use the employees of the three-star hotel in Batam. The research used questioner as the media to collect the data and the amount of question 31 items. Data is processed using SPSS for demographics and common method biases (CMB) analysis and SmartPLS for hypothesis testing.

\section{A. Common Method Biases (CMB)}

Is a collection of data obtained from a single source such as a questionnaire [19]. One of the factor tests used to collect the effects of CMB. Required not to occur CMB if varians value less than $50 \%$. SPSS program is carried out to test the effects of CMB.

\section{B. Data Quality Test}

Validity test is testing the accuracy of the measuring instruments used in research. The value of AVE (Average 
Variance Extracted (AVE) is equal to 0.5 or more [20], while the reliability test to test the consistency of answers to questions, Composite Reliability and Cronbach's Alpha are accepted if the value is equal to 0.6 or more [21].

Path Coefficient or direct effect evaluates the relationship (structural path), Indirect Effect or indirect effect is useful for analyzing the strength of the relationship between the mediator with other variables [20].

Determination Coefficient Test $\left(\mathrm{R}^{2}\right)$ to assess how much an endogenous construct can be explained by an exogenous construct. According to Sarstedt et al. (2017) expected value of the coefficient of determination $(R \wedge 2)$ between 0 and $1 . R$ Square value is weak $=0.25$; moderate $=0.50$; and strong $=$ 0.75 .

\section{RESUlTS AND DisCUSSION}

\section{A. Results}

Collecting data in this research is done by spreading questioner to 123 respondents. The collecting of the data questioners is spread in two weeks. The spreading questioners are 123 and 30 questioners were not return. There are no uncompleted questioners so, the total of questioners are 90. Questioners in this research gave to the employee in Barelang Hotel, Batam City Hotel, Batam Harbour Hotel, Da Vienna Hotel, Gideon Hotel, Harmoni Hotel, Utama Hotel, The Hills Hotels, Nagoya Plasa Hotel, swiss inn Hotel, The King hotel.

The amount of gender the responden from 93. The male responden $53,8 \%$ from 83 or 50 responden, meanwhile the female responden are $46,2 \%$ or 43 respondents. Can be seen on Table 4 that male responden is more than female respondents. The amount responden based on age from 93 responden. The number of respondents that 18 years old until 20 years old are $9,7 \%$ or 9 responden. The number of respondents, 21 years old until 25 years old are 39,8 or 37 respondents. The number of respondents, 26 years old until 30 years are $30,1 \%$ or 28 respondents. The number of respondents, more than 30 years old are $20,4 \%$ or 19 respondents. Can be seen on the table 4 that the amount of respondent ages are 21 years old until 25 years old. The number of respondents based on the education from 93 respondents. The education of respondent, SMK/SMA are $54,8 \%$ or 51 respondents. Respondents from D3 are $17,2 \%$ or 16 respondents. Can be seen from table 4 that from the education level, the most, respondents are SMA/SMK, 51 respondents from 93 respondents.

The number of respondents from the time of work. From 93 respondents. Respondents with the worktime 1-2 years are $48,8 \%$ or 45 respondents. Respondent from the worktime 3-5 years are $26,9 \%$ respondents or 25 respondents. Respondent from the worktime, more than 5 years are $24,7 \%$ or 23 respondents. Can be seen that the most respondents have work time, 1-2 years, that are 45 respondents.
TABLE IV. DEMOGRAPHIC RESPONDENT

\begin{tabular}{|l|l|l|}
\hline \multicolumn{1}{|c|}{ Gender } & Total & Persen \\
\hline Male & 50 & $53.8 \%$ \\
\hline Female & 43 & $46.2 \%$ \\
\hline Total & 93 & $100 \%$ \\
\hline Old & Total & Persen \\
\hline Year 18-20 & 9 & $9.7 \%$ \\
\hline Year 21 -25 & 37 & $39.8 \%$ \\
\hline Year 26-30 & 28 & $30.1 \%$ \\
\hline >=Year 30 Tahun & 19 & $20.4 \%$ \\
\hline Total & 93 & $100 \%$ \\
\hline Education level & Total & Persen \\
\hline High school/SMK & 51 & $54.8 \%$ \\
\hline D3/Diploma & 16 & $17.2 \%$ \\
\hline Undergraduate & 26 & $28 \%$ \\
\hline Total & 93 & $100 \%$ \\
\hline Year of service & Total & Persen \\
\hline Year 1 - 2 & 45 & $48.4 \%$ \\
\hline Year 3-5 & 25 & $26.9 \%$ \\
\hline >=5 Tahun & 23 & $24.7 \%$ \\
\hline Total & 93 & $100 \%$ \\
\hline \multicolumn{2}{|l|}{ Source: Primary data managed, 2019. }
\end{tabular}

Test CMB done with the software IBM SPSS version 23 . Based on the Single Factor Test used IBM SPSS version 23, the variant score to the research $31,63 \%$ or less than $50 \%$. So, it concluded in this research, there is no common method biases. The data source in this research use the appropriate respondents, that are the employee of Barelang Hotel, Batam City Hotel, Gideon Hotel, Batam Harbour Boutique Hotel, Da Vienna Hotel, Harmoni hotel, Nagoya Plasa Hotel, Gideon Hotel, Swiss in Hotel, The K hotel, Utama Hotel.

Test outer loading is to know the load of each factor's indicator to variable. A question can be said valid if the outer loading $>0,5 \%$ or more than 0,5 [22]. Indicator that is not significant have to erase because the question can be used on the next test. AVE can be used as the test of validity convergent and divergent [20]. The AVE score must be more than 0.5 to show the validity convergent from construct.

The reliability can be reliable if have score or Composite Reliability, 0,6 or more [20]. A relation on Path Coefficient can be said significant by the significant level $5 \%$. If it has $\mathrm{T}$ statistics score more than 1,96 or P-values $<0.05$ is the test of Path coefficient between Intention to Share Knowledge, Leader Member Exchange, Employee creativity.

1) Hypothesis 1: Intention to Share Knowledge ( $\mathrm{H} 1)$ has $\mathrm{T}$-statistics score and $\mathrm{P}$-values that positive significant is 4,008 and 0,000; where T-statistics is more than 1,96 and P-values not more than 0,05 [21]. This is show that intention to share knowledge has positif influence to employee creativity. The result of the research support the research that done by Shu Hsien Liao, Chih Chiang Chen, Da Chian $\mathrm{Hu}$ which the research found intention to share knowledge has positive influence with employee creativity [9]. Example: department sales suggest new way to increase the quality of hotel market to the customer. The results of path coefficient can be seen on table 5 . 
TABLE V. The RESUlt OF PATH COEFFICIENT

\begin{tabular}{|l|l|l|l|}
\hline $\mathrm{X} \rightarrow \mathrm{Y} /$ Direct Effect & \multicolumn{1}{|c|}{$\begin{array}{c}\text { T-statistics } \\
(>1.96)\end{array}$} & $\begin{array}{c}\text { P-values } \\
(<0.05)\end{array}$ & \multicolumn{1}{|c|}{ Result } \\
\hline $\begin{array}{l}\text { Intention to Share } \\
\begin{array}{l}\text { Knowledge } \rightarrow \text { Employee } \\
\text { Creativity }\end{array}\end{array}$ & 4.008 & 0.000 & $\begin{array}{l}\text { H1: Positive } \\
\text { Significant }\end{array}$ \\
\hline
\end{tabular}

Source: Primary data managed, 2019

A relation on Indirect Effect can be said significant with the level of significancy $5 \%$. If it has T-statistics score more than 1,96 or P-values $<0.05[20]$. Table 6 is the result of test Indirect Effect between Intention to Share Knowledge dan Employee Creativity.

TABLE VI. THE RESUlT OF THE INDIRECT EFFECT

\begin{tabular}{|l|l|l|l|}
\hline $\mathrm{X} \rightarrow \mathrm{Y} /$ Indirect & \multicolumn{1}{|c|}{$\begin{array}{c}\text { T-statistics } \\
(>1.96)\end{array}$} & $\begin{array}{c}\text { P-values } \\
(<0.05)\end{array}$ & \multicolumn{1}{|c|}{ Result } \\
\hline $\begin{array}{l}\text { Intention to Share } \\
\text { Knowledge } \rightarrow \text { Employee } \\
\text { Creativity }\end{array}$ & 2.503 & 0.013 & $\begin{array}{l}\text { Positive } \\
\text { Significant }\end{array}$ \\
\hline
\end{tabular}

Source: Primary data managed, 2019

2) Hypothesis 2: Intention to Share Knowledge (H2) has $\mathrm{T}$-statistics score and $\mathrm{P}$-values that positive significant is 2,503 and 0,013; where T-statistics is more than 1,96 and P-values not more than 0,05 [21]. This is show that mediating leader member exchange has positif influence between intention to share knowledge and employee creativity. The result described on table 7.

TABLE VII. The Result Test of Structural MOdel with VARIABLE OF MEDIATION /INTERVENING

\begin{tabular}{|l|l|l|l|}
\hline \multicolumn{1}{|c|}{$\begin{array}{c}\mathrm{X} \rightarrow \mathrm{M} \rightarrow \mathrm{Y} / \\
\text { Intervening }\end{array}$} & $\begin{array}{c}\text { T-statistics } \\
(>1.96)\end{array}$ & $\begin{array}{c}\text { P-values } \\
(<0.05)\end{array}$ & \multicolumn{1}{|c|}{ Result } \\
\hline $\begin{array}{l}\text { Intention to Share } \\
\text { Knowledge } \rightarrow \text { Leader } \\
\text { Member Exchange } \rightarrow\end{array}$ & 2.503 & 0.013 & $\begin{array}{l}\text { H2: Positive } \\
\text { significant }\end{array}$ \\
Employee Creativity & & & \\
\hline
\end{tabular}

Source: Primary data managed, 2019

The result of the test determination coefficient $\left(\mathrm{R}^{2}\right)$ to test the relation of independent variable, mediation variable and depended variable or to test the correlation. On table 7, the relation between Intention to Share Knowledge and Leader Member Exchange influenced Employee Creativity has $\left(\mathrm{R}^{2}\right)$, $0,391(39 \%)$ or Employee Creativity influenced Intention to Share Knowledge and Leader Member Exchange is 39,1\% meanwhile $60,9 \%$ influenced identification variable as task motivation and identification with leader. The relation between Intention to Share Knowledge and Employee Creativity influenced Leader Member Exchange has R ${ }^{2} 0,199$ (19,9\%) or Leader Member Exchange influence Intention Variable Share Knowledge and Employee Creativity influenced is 19,9\% meanwhile the rest $80,1 \%$ influence team intention to share knowledge and moral leadership variable. The results of test $\mathrm{R}^{2}$ can be seen on table 8 .
TABLE VIII. THE RESULT TEST $\mathrm{R}^{2}$

\begin{tabular}{|l|l|l|}
\hline \multicolumn{1}{|c|}{ Variable } & Sample Mean & Percent (\%) \\
\hline Employee Creativity & 0.391 & $39.1 \%$ \\
\hline Leader Member Exchange & 0.199 & $19.9 \%$ \\
\hline \multicolumn{2}{|c|}{ Source: Primary data managed, 2019.}
\end{tabular}

\section{B. Discussion}

The research is the first case study that investigate the manner of intention to share knowledge and the influence to leader member exchange and employee creativity in three-star hotel. All the stake holder does a must to manager and employee to improve the competive individual, team and organization in hotel industry, if it is not, it will be disappearing easily because of the strong competition.

Although this research is to avoid the mistake and the research make sure that the process fulfills the statistic method, this research has weakness. First, the sample of this research is less because the data from 11 three-star hotels and the sample of 193 employees. Second, the research make survey to the want of the employee to share knowledge each other to improve the employee creativity in three-star hotel. Third, the lack of source or journal to support mediating hypothesis.

\section{CONCLUSION}

Based on the research, the writer concludes some things are: a) Intention to share knowledge has significant relation with employee creativity. b) Intention to share knowledge has significant relation with employee creativity through leader member exchange. The next research that is suggested by the author is, this research's opinion is that intention to share knowledge influence leader member exchange after that influence employee creativity. The next research is needed to test the feedback in intention to share knowledge.

\section{REFERENCES}

[1] A.H.Y. Hon, "Does job creativity requirement improve service performance? A multilevel analysis of work stress and service environment," International Journal of Hospitality Management, vol. 35, pp. 161-170, 2013.

[2] J.S. Horng, C.H. Liu, S.F. Chou, and C.Y. Tsai, "Creativity as a critical criterion for future restaurant space design: Developing a novel model with DEMATEL application," International Journal of Hospitality Management, vol. 33, no. 1, pp. 96-105, 2013.

[3] G. Richards, "Creativity and tourism. The state of the art," Annals of Tourism Research, vol. 38, no. 4, pp. 1225-1253, 2011.

[4] C.J. Wang, H.T. Tsai, and M.T. Tsai, "Linking transformational leadership and employee creativity in the hospitality industry: The influences of creative role identity, creative self-efficacy, and job complexity," Tourism Management, vol. 40, pp. 79-89, 2014.

[5] BPS. [online]. Retrieved from https://batamkota.bps.go.id

[6] C.L. Byrne, M.D. Mumford, J.D. Barrett, and W.B. Vessey, "Examining the leaders of creative efforts: What do they do, and what do they think about?" Creat Innov Manag, vol. 18, no. 4, pp. 256-68, 2009.

[7] S.H. Liao and C.C. Wu, "The Relationship among Knowledge Management, Organizational Learning, and Organizational Performance," Int J Bus Manag, vol. 4, no. 4, pp. 64-76, 2009. 
[8] S.K. Tan, D.B. Luh, and S.F. Kung, "A taxonomy of creative tourists in creative tourism," Tour Manag, vol. 42, pp. 248-59, 2014.

[9] S.H. Liao, C.C. Chen, and D.C. Hu, "The role of knowledge sharing and LMX to enhance employee creativity in theme park work team," Int J Contemp Hosp Manag, vol. 30, no. 5, pp. 2343-59, 2018.

[10] K.M. Bartol and A. Srivastava, "Encouraging Knowledge Sharing: The Role of Organizational Reward Systems," J Leadersh Organ Stud, vol. 9, no. 1, pp. 64-76, 2002.

[11] Y.A. Sothan, "Study on Correlation between Leader-Member Exchange and Employee Creativity: The Impacts of Knowledge Sharing and Organizational Commitment,” Int Rev Manag Bus Res, vol. 5, no. 2, pp. 688-704, 2016.

[12] B.V.D. Hooff and J.A. Ridder, "Knowledge sharing in context: The influence of organizational commitment, communication climate and CMC use on knowledge sharing," J Knowl Manag, vol. 8, no. 6, pp. 117-30, 2004.

[13] T.M. Amabile, R. Conti, H. Coon, J. Lazenby, and M. Herron, “Assessing the work environment for creativity," Acad Manag J, vol. 39, no. 5, pp. 1154-84, 1996.

[14] S.H. Liao and C.C. Chen, "Leader-member exchange and employee creativity," Leadersh Organ Dev J, vol. 39, no. 3, pp. 419-35, 2018.

[15] J. Gu, G. Wang, Liu, D. Song, and C. He, "Linking Authoritarian Leadership to Employee Creativity: The Influences of Leader Member Exchange, Team Identification and Power Distance," Chinese Manag Student, vol. 12 , no. 2, pp. 384-406, 2018
[16] M. Zaitouni and M.L. Ouakouak, "Key Predictors of Individual Creativity In A Middle Eastern Culture: The Case of Service Organizations," International Journal of Organizational Analysis, vol. 26, no. 1, pp. 19-42, 2018.

[17] C.N. Karabey and Z.D. Aliogullari, "The Impact of Ethical Leadership on Member's Creativity and Career Success: The Mediating Role of Leader Member Exchange," Research Journal of Business and Management, vol. 5, no. 3, pp. 202-211, 2018.

[18] A.M.B.C.A.A. Angreni, "Laju Hotel di Bali dan Batam Sangat Pesat," Bisnis.com, 2018

[19] P.M. Podsakoff, S.B. MacKenzie, J.Y. Lee, and N.P. Podsakoff, "Common Method Biases in Behavioral Research: A Critical Review of the Literature and Recommended Remedies," Journal of Applied Psychology, vol. 88, no. 5, pp. 879-903, 2013.

[20] T. Taylor and S. Geldenhuys, "Using Partial Least Squares to Measure Tourism Students' Satisfaction with Work-Integrated Learning," Tourism, pp. 1-20, 2019.

[21] M. Sarstedt, J.F. Hair, and C.M. Ringle, Partial Least Squares Structural Equation Modeling. In C. Homburg, M. Klarmann, \& A. Vomberg (Eds.), Handbook of Market Research, 2017, pp. 1-40.

[22] J.F. Hair, C.M. Ringle, G.T.M. Hult, and M.A. Sarstedt, "rimer on Partial Least Squares Structural Equation Modeling (PLS-SEM). 2nd ed. SAGE Publications, Inc; 2017. 